\title{
The role of halal awareness, halal certification, and marketing components in determining halal purchase intention among non-Muslims in Malaysia: a structural equation modeling approach
}

\begin{abstract}
Although the important role of halal awareness, halal certification, and marketing-related components in determining purchase intention has been recognized in the marketing literature, empirical examination of this issue is limited. In order to fill this knowledge gap, this study aimed to determine the relationships between halal awareness, halal certification, food quality, marketing promotion, and brand with the intention to purchase halal product among the non-Muslim community in Malaysia. The data were collected through a selfadministered questionnaire survey consisting of 226 non-Muslim consumers. Structural equation analyses indicated that the halal awareness, halal certification, marketing promotion, and brand were positively related to purchase intention, whereas food quality was negatively associated with it. Theoretically, this study is one of the first attempts to develop and to empirically test a conceptual model on halal purchase intention by integrating halal components with marketing-related components.
\end{abstract}

Keyword: Halal awareness; Halal certification; Malaysia; Purchase intention 